\section{Pure testicular teratoma in adults: experience in the treatment of 49 consecutive cases}

\author{
Djordje M. Argirović ${ }^{1}$, Aleksandar Dj. Argirović \\ ${ }^{1}$ Clinic of Urology, Clinical Center of Serbia, Outpatient \\ Clinic "Argirovic", Urology, Belgrade, Serbia \\ ${ }^{2}$ Clinical Hospital Center “Zemun”, Department of Urology, \\ Belgrade, Serbia
}

\section{Abstract}

The aim of the present study is to analyse fate and survival in patients with pure testicular teratoma (PTT) according to clinical stage (CS) and applied therapy. Among a survey of 1275 patients with nonseminomatous germ cell testicular tumors (NSGCT) observed from January 1982 and June 2005, we indentified 49 (4\%) patients with PTT. In CS I, $3(15 \%)$ of 20 patients on surveillance relapsed. Complete response (CR) is achieved with chemotherapy in 1 patient and combined with postchemotherapy retroperitoneal lymphadenectomy (PC RPLA) in 2 patients (fibrosis 1, teratoma 1). Four patients managed with primary RPLA had universal survival. Among 4 patients treated initially with primary chemotherapy due to persistently elevated serum tumor markers (STMs) postorchiectomy, 1 patient died at 18 months. In CS I, 27 (96\%) of 28 patients are alive and free of disease (AFD) at median follow-up (MFU) of 161.6 months. In the PC group, 1 patient with partial response (PR) is lost to follow-up at 6 months, 1 patient died of disease at 27 months. Eight patients achieved CR with induction chemotherapy, whereas only 1 patient relapsed at 24 months and is rendered free of disease with RPLA (teratoma). Twelve patients underwent PC RPLA due to PR following induction chemotherapy, combined with thoracic cytoreductive surgery in 2 patients. RP histology demonstrated the finding of fibrosis in 2 , teratoma in 8 , teratoma with malignant transformation in 1 , and vital carcinoma in 1 . The patients with fibrosis, teratoma and teratoma with malignant transformation are AFD, whereas the patient with vital carcinoma on desperation RPLA died. According to initial CS IIB, IIC and III PC surgery was indicated in 20\%, $91 \%$ and $50 \%$, relapse rate was $0 \%, 18 \%$ and $20 \%$, with disease specific survival (DSS) in $100 \%, 90 \%$ and $100 \%$, respectively. At MFU of 189.7 months, 19 (95\%)

\section{Čist teratom testisa kod odraslih: iskustvo u lečenju 49 konsekutivnih slučajeva}

\author{
Đorđe M. Argirović1 ${ }^{\text {, Aleksandar Đ. Argirović }}{ }^{2}$ \\ ${ }^{1}$ Urološka Klinika, Klinički Centar Srbije, Poliklinika \\ "Argirović", Urologija, Beograd, Srbija \\ ${ }^{2}$ Kliničko Bolnički Centar “Zemun”, Urološko odeljenje, \\ Beograd, Srbija
}

\section{Apstrakt}

Cilj ove studije je da analizira evoluciju i preživljavanje kod pacijenata s čistim teratomom testisa (ČTT) u zavisnosti od kliničkog stadijuma (KS) i primenjene terapije. U seriji od 1275 pacijenata sa neseminomskim tumorima germinativnih ćelija testisa opserviranih od januara 1982 do juna 2005, indentifikovali smo 49 (4\%) pacijenata sa ČTT. U KS I, 3 (15\%) od 20 pacijenata koji su samo praćeni, su imali recidiv. Jedan pacijent je preveden u kompletnu remisiju (KR) samo pomoću hemioterapije i dvoje u kombinaciji sa posthemioterapijskom retroperitonealnom limfadenektomijom (PHT RPLA) (fibroza 1, teratom 1). Četiri pacijenta lečena sa primarnom RPLA su imala univerzalno preživljavanje. Od 4 pacijenata tretiranih sa primarnom hemioterapijom zbog perzistentno povišenih vrednosti tumorskih markera u serumu posle orhiektomije, 1 pacijent je umro posle 18 meseci. U KS I, 27 (96\%) od 28 pacijenata je živo i bez znakova bolesti za srednje praćenje od 161.6 meseci. U PHT grupi, 1 pacijent sa parcijalnim odgovorom (PO) je izgubljen iz praćenja kod 6 meseci, 1 pacijent je umro od primarne bolesti posle 18 meseci. Osam pacijenata je postiglo KR sa indukcionom HT, dok je samo 1 pacijent imao recidiv posle 24 meseci i preveden je $u$ KR sa RPLA (teratom). Dvanaest pacijenata je podvrgnuto PHT RPLA zbog PO na indukcionu hemioterapiju, kombinovanu sa torakalnom citoreduktivnom hirurgijom kod 2 pacijenta. RP histologija je pokazala nalaz fibroze kod 2 , teratoma kod 8 , teratoma sa malignom transformacijom kod 1, i vitalnog karcinoma kod 1. Pacijenti sa nalazom fibroze, teratoma i teratoma sa malignom transformacijom su živi i bez znakova bolesti, dok je pacijent sa vitalnim karcinomom umro. Prema inicijalnom KS IIB, IIC i III PHT hirurgija je bila indikovana kod 20\%, 91\% i 50\%, učestalost recidiva je bila $0 \%, 18 \%$ i $20 \%$ i preživljavanje u $100 \%, 90 \%$ i $100 \%$, respektivno. Kod srednjeg praćenja od 189.7 meseci, 19 (95\%) od 20 pacijenata 
of 20 fully available patients are AFD. Overall, 46 (94\%) patients had no evidence of disease (NED) at last follow-up. These data underscore the metastatic potential of PTT. A significant proportion $(32 \%)$ of patients with low-stage PTT had RP disease. Furthermore, a high proportion (36\%) presented initially with advanced disease and demonstrated a considerable risk of relapse despite complete resection or favorable histologic features in the resected surgical specimen.

Key words: testis, germ cell tumors, teratoma, surveillance, chemotherapy, surgery dostupnih punoj evaluaciji je živo i bez znakova bolesti. Sveukupno, 46 (94\%) pacijenata je bilo bez znakova bolesti pri poslednjoj kontroli. Ovi nalazi govore u prilog metastatskog potencijala (ČTT). Značajan procenat $(32 \%)$ pacijenata sa niskim KS ČTT je imao RP metastatsku bolest. Štaviše, visok procenat (36\%) pacijenata su se inicijalno prezentirali sa uznapredovalim KS i pokazali da postoji značajan rizik od recidiva uprkos kompletne resekcije ili povoljnog histološkog nalaza u reseciranom hirurčkom preparatu.

Ključne reči: testis, tumori germinativnih ćelija, teratom, praćenje, hemioterapija, hirurgija

\section{Introduction}

Teratomatous elements, occur in $55 \%$ to $79 \%$ of primary NSGCT ${ }^{1-6}$, with PTT comprising $2 \%$ to $6 \%{ }^{1,7-9}$ of cases. Given reports of a lower incidence of retroperitoneal (RP) disease and relapse in CS I mixed NSGCT with a predominant component of teratoma in the primary tumor, these patients have been considered candidates for surveillance $2,4,5$. Although PTT have a benign course in prepubertal children 10, in adults metastasis have been reported in $27 \%$ to $46 \%{ }^{6,8,11,12}$ of cases at presentation. Furthermore, RP metastasis have been indentified in $17 \%$ to $29 \%$ of patients with CS I PTT treated with primary RPLA ${ }^{11.12,13}$. Given the rarity of this latter histologic finding in adults with NSGCT, controversy exists in published reports regarding the most appropriate management of the RP after radical orchiectomy. Some investigators recommend surveillance ${ }^{8,9}$ while others recommend RPLA ${ }^{11-14}$. The present study was conducted to determine the clinical outcome of patients with PTT who underwent surveillance, cisplatin (CDDP)-based chemotherapy, primary RPLA and PC RPLA.

\section{Material and Methods}

\section{STUDY POPULATION}

Between January 1982 and June 20051275 patients were managed for testicular NSGCT. Forty-nine (3.8\%) of these patients had a PTT, of whom 28 were in CS I and 28 were in CS IIB, IIC and III. These 49 patients formed the subject of this report.

\section{CLINICAL STAGE I NSGCT GROUP}

The 28 patients with PTT underwent surveillance $(n=20)$, primary RPLA $(n=4)$ and primary CDDP-based chemotherapy due to persistently elevated STMs postorchiectomy $(n=4)$, ranged in age from 14 to 59 years (median 28.9). Twenty-four patients had normal STMs, alpha-fetoprotein (AFP) and beta human chorionic gonadotropin (beta hCG), at presentation. Four patients had persistently elevated STMs postorchiectomy: 3 elevated AFP (median 116, range 61.3-225 ng/ml) and 1 elevated beta hCG $(24.3 \mathrm{mIU} / \mathrm{L})$. The primary tumor was mature teratoma (MT) in $16(57.1 \%)$ patients and immature teratoma (IMT) in $12(42.9 \%)$ patients. All 28 patients were classified to be good IGCCCG prognostic group.

\section{METASTATIC NSGCT GROUP}

The 21 patients with metastatic PTT underwent induction CDDP-based chemotherapy, ranged in age from 17 to 57 years (median 29.3). The indication for PC RPLA for NSGCT was a PC computed tomography scan revealing a residual mass, whereas residual extraretroperitoneal metastatic disease was resected as indicated. The initial CS was Stage IIB in 5 (23.8\%) patients, Stage IIC in 11 (52.4\%) patients and Stage III in $5(23.8 \%)$ 
patients. One patient had elevated beta hCG before PC RPLA. The primary tumor was MT in 11 (52.4\%) patients and IMT in $10(47.6 \%)$ patients. The other site in the 5 CS III was lung (2 patients), lung and mediastinal lymph nodes ( 2 patients) and liver, supraclavicular lymph nodes and lung (1 patient). IGCCCG risk classification for patients with metastatic disease was as follows: good (15 patients), intermediate (4 patients) and poor (2 patients). Among 21 patients with metastatic disease, 14 PC surgical procedures were performed: RPLA (12), combined with nephrectomy (1) and lung metastasectomy with extirpation of enlarged mediastinal lymph nodes (2).

\section{FOLLOW-UP}

Postoperatively, patients were followed-up every 2 months in the first year, every 3 months in the second year, every 4 months in the third year, every 6 months in the fourth and fifth year, and annually thereafter. At each visit, history, physical examination, the chest $\mathrm{x}$-ray, ultrasound of the abdomen, minor pelvis and scrotum were performed and STMs levels determined, including AFP, beta hCG and lactate dehydrogenase. Computed tomography was performed at 6 months, during first 2 years.

\section{Results}

\section{CLINICAL STAGE I NSGCT GROUP}

Among 20 patients undergoing surveillance, 3 (15\%) relapsed within median free interval (MFI) of 16.3 months (range 6-33) (1 RPLN, 1 lung, 1 RP and cervical LN, liver, lung). All relapsing patients are rendered free of disease: 1 with CDDP-based chemotherapy alone and 2 combined with PC RPLA (fibrosis 1, teratoma 1). At MFU of 154.05 months all patients are AFD. Four patients managed with primary RPLA had universal survival at MFU of 258.2 months. All 4 patients with persistently elevated STMs postorchiectomy achieved CR following induction CDDP-based chemotherapy. One patient relapsed at 6 months with metastasis in the RP LN and spine, and died after 18 months despite salvage chemotherapy and radiotherapy, whereas 3 patients remained continuously free of disease at MFU of 131.3 months. Overall, DSS is achieved in 27 (96\%) patients at MFU of 161.4 months. Two patients developed metachronous GCT, at 57 and 111 months from initial diagnosis. Second GCT was in CS I, 1 patient had discordant histology, and 1 patient was managed with testicular sparing surgery for the $2^{\text {nd }} \mathrm{GCT}$. Both patients underwent surveillance for the $2^{\text {nd }} \mathrm{GCT}$ and remained continuously with NED. However, 4 patients died of other causes while disease-free: ischemic heart disease ( 2 patients), pancreatic cancer (1 patient) and malignant melanoma (1 patient) (Table 1.).

Table 1. Fate and survival in clinical stage I PTT: surveillance vs. RPLA vs. chemotherapy

\begin{tabular}{|c|c|c|c|}
\hline \multirow{2}{*}{ CHARACTERISTICS } & \multicolumn{3}{|c|}{ TREATMENT } \\
\hline & Surveillance & RPLA & Chemotherapy \\
\hline No of patients & 20 & 4 & 4 \\
\hline Relapse & $3(15 \%)$ & - & $1(25 \%)$ \\
\hline $\begin{array}{l}\text { MFI to relapse, months } \\
\text { (range) }\end{array}$ & $16.3(6-33)$ & - & 6 \\
\hline Localization of relapses & $\begin{array}{c}\text { RPLN (1), RP + cervical } \\
\text { LN, lung, liver (1), lung } \\
\text { (1) }\end{array}$ & - & RPLN - spine \\
\hline $\begin{array}{l}\text { CR following therapy in } \\
\text { relapse }\end{array}$ & $(100 \%)$ & - & 0 \\
\hline Chemotherapy \pm Rtx & 1 & & 0 \\
\hline Chemotherapy \pm RPLA & 2 (teratoma 1 , fibrosis 1$)$ & & \\
\hline DSS & $20(100 \%)$ & $(100 \%)$ & $3(75 \%)$ \\
\hline MFU, months (range) & 154,5 (95-299) & $258(191-342)$ & $103(18-161)$ \\
\hline
\end{tabular}




\section{METASTATIC NSGCT GROUP}

Four (80\%) of 5 patients in CS IIB achieved CR with CDDP-based chemotherapy alone. One (20\%) patient necessitate PC RPLA due to residual RP disease and with finding of teratoma in surgical specimen. All patients are AFD at MFU of 177 months. Only 2 (18.2\%) of 11 patients in CS IIC achieved CR following induction CDDP-based chemotherapy, whereas 1 patients relapsed in RP LN at 24 months and is rendered free of disease with PC RPLA containing teratoma in surgical specimen. Nine $(81.8 \%)$ patients underwent PC RPLA with finding of fibrosis in $2(22.2 \%)$ patients, teratoma in $5(55.6 \%)$ patients, vital carcinoma in 1 $(11.1 \%)$ patient, and teratoma with malignant transformation in $1(11.1 \%)$ patient. The patients with finding of fibrosis, teratoma and teratoma with malignant transformation had universal survival, whereas the patient with vital carcinoma submitted to desperation PC RPLA died at 27 months. One patient died of stroke while be free of primary tumor.

One patient in CS III with far advanced metastatic disease is lost of follow-up at 6 months after partial response and probably died. Two patients achieved CR with chemotherapy alone. Two patients underwent PC RPLA with finding of teratoma, combined with cytoreductive surgery of lung and mediastinal lymph nodes metastasis. One patient had discordant lung histology versus RP (vital carcinoma), Four fully available patients are AFD at MFU of 202.2 months. One patient relapse at 10 months following cytoredutive thoracic surgery with teratomatous metastasis in mediastinal lymph nodes and is rendered free of disease with redo operation. (Table 2.).

Table 2. Fate and survival in patients with metastatic PTT: CDDP-based chemotherapy \pm surgery

\begin{tabular}{|c|c|c|c|}
\hline \multirow{2}{*}{ CHARACTERISTICS } & \multicolumn{3}{|c|}{ CLINICAL STAGE } \\
\cline { 2 - 4 } & IIB & IIC & III \\
\hline No of patients & 5 & 11 & 1 \\
\hline $\begin{array}{c}\text { Lost of follow-up } \\
\begin{array}{c}\text { CR to Chemotherapy } \\
\text { alone }\end{array}\end{array}$ & 0 & 0 & $2(40 \%)$ \\
\hline PC-surgery & $1(80 \%)$ & $2(18 \%)$ & $2(40 \%)$ \\
\hline -grossly free of disease & $1(20 \%)$ & $9(82 \%)$ & $2(40 \%)$ \\
\hline -serologic remission & $1(20 \%)$ & $9(82 \%)$ & $2(40 \%)$ \\
\hline Relapse following CR & - & $8(73 \%)$ & $1(25 \%)$ \\
\hline $\begin{array}{c}\text { CR following therapy } \\
\text { in relapse }\end{array}$ & - & $2(18 \%)$ & $1(100 \%)$ \\
\hline Died & - & $1(50 \%)$ & $1(20 \%)$ \\
\hline DSS & $5(100 \%)$ & $10(9 \%)$ & $4(80 \%)$ \\
\hline $\begin{array}{c}\text { MFU, months } \\
\text { (range) }\end{array}$ & $177(128-238)$ & $166,5(27-264)$ & $177,4(198-242)$ \\
\hline
\end{tabular}

Overall, $21(43 \%)$ patients presented initially with metastatic disease, whereas $16(33 \%)$ had bulky metastasis. If we include in the present analysis relapsing patients, $25(51 \%)$ patients with PTT had metastasis, whereas 23 (45\%) patients had isolated RP LN involvement. Fourteen (28.6\%) patients underwent PC RPLA and $18(38.7 \%)$ had CS IIC or higher. The pathologic evaluation of nodes after PC RPLA demonstrated the presence of fibrosis in $3(21.4 \%)$ patients, teratoma in $9(64.4 \%)$ patients, teratoma with malignant transformation in $1(7.1 \%)$ patient and vital carcinoma in $1(7.1 \%)$ patient. Only the patient with vital carcinoma died, whereas the patients with fibrosis, teratoma, and teratoma with malignant transformation are AFD. At MFU of 165.9 months, 47 (96\%) patients are AFD. Two (4\%) patients died of widespread metastasis within median survival time of 22.5 months. The present study demonstrated that extraretroperitoneal resection had any impact on final outcome. 


\section{Discussion}

We indentified 49 (3.8\%) patients with PTT undergoing different mode of treatment according to CS for NSGCT, consistent with the incidence reported in other series ${ }^{1,7-9}$. Given the rarity of this histologic finding in adults with testicular NSGCT, there is controversy in published reports regarding the most appropriate management of the RP in these cases. Our data support recent studies that have favored RPLA for low-stage disease ${ }^{11-13}$.

In our cohort of patients managed for PTT, 16 (32.6\%) of 49 patients presented with bulky RP (CS IIC) or metastatic (CS III) disease, highlighting the malignant potential of this histologic finding in adults compared with the more benign course in prepubertal children. Our 32.6\% incidence of patients presenting with advanced CS (IIC-III) is similar to the $39 \%$ incidence reported by Leibovitch et al. ${ }^{11}$ and $20.5 \%$ incidence reported by Heidenreich et al. ${ }^{15}$, but lower than $59 \%$ incidence reported by Rabbani et al. ${ }^{12}$ a difference that may be accounted be refer all bias, as well as the small number of patients in all these series from referral centers. Although Rabbani et al. ${ }^{12}$, Heidenreich et al. ${ }^{13}$, noted no relapse in patients undergoing primary RPLA, Leibovitch et al. ${ }^{11}$, indentified relapse rate of $11 \%$ (2 of 18) for CS I disease. Both patients with relapse in the series of Leibovitch and associated ${ }^{11}$ had RP disease at RPLA. We indentified no relapse in 4 patients submitted to primary RPLA, and 1 relapse in RP LN and spine of 4 patients managed with primary CDDPbased chemotherapy due to persistently elevated STMs following orchiectomy. Heidenreich et al. ${ }^{13}$ reported that of 20 patients with PTT having metastasis, $16(80 \%)$ had scar and calcifications in the remaining testicular parenchyma, suggestive of a burn-out tumor, and $4(20 \%)$ had microfocal embryonal cell carcinoma. This finding suggests a potential mechanism of metastasis whereby undifferentiated stem cells in the primary testicular tumor may metastasize, and then differentiate into teratoma and other GCTs at the site of metastasis. The investigators suggested a risk-based strategy in which patients with teratoma and a burnt-out tumor in the testis undergo RPLA, and those with PTT in the testis may be considered for surveillance ${ }^{13}$.

Some investigators have advocated only surveillance approach to patients with CS I disease with PTT. Although Freedman et al. ${ }^{4}$ and Read et al. ${ }^{9}$, respectively, reported a $100 \%$ and $95 \%$ 2-year relapse-free rate in 11 and 22 CS I patients with PTT managed by surveillance. Stevens et al. ${ }^{7}$, reported relapse in 1 of 7 patients and Simmonds et al. ${ }^{8}$ reported in 2 of 10 with CS I PTT managed by surveillance. Although the higher incidence of RP teratoma in patients with teratoma in the orchiectomy specimen compared with those without teratoma ${ }^{15-17}$ argues for primary RPLA in CS I and IIA disease ${ }^{11,13}$, in the surveillance series ${ }^{4,7-9}$, only $4(8 \%)$ of 50 patients with CS I disease developed relapse. Among 20 patients in our series managed with surveillance only $3(15 \%)$ relapsed, with 2 patients necessitating PC RPLA due to RP metastatic disease. This discrepancy suggests that some patients with microscopic teratoma in the RP at RPLA may be biologically inert disease not destined to relapse. However, it is unknown how many of these $92 \%$ who are disease free during surveillance may experience a late relapse. Primary RPLA may prevent some of the potential risk of unresected teratoma, including late relapse ${ }^{19-21}$, malignant transformation ${ }^{22}$ and the growing teratoma syndrome ${ }^{23}$.

The presence of teratoma in the primary tumor has previously been reported to predict for an incomplete response to induction chemotherapy in patients with advanced disease ${ }^{24}$. Rabbani et al. ${ }^{25}$ reported that in patients treated with CDDP-based induction chemotherapy for CS II-III testicular NSGCT, those with teratoma in the primary tumor had a lower radiologic response ( 5 of 22 or $23 \%$ ), defined as residual mass of 15 $\mathrm{mm}$ or less, compared with those with no teratoma in the primary tumor ( 27 of 50 or $54 \%$; $\mathrm{P}=0.014$ ). In the 39 patients undergoing RPLA after chemotherapy, the incidence of teratoma in the RP nodes was 67\% (12 of 18 patients) and $29 \%$ (6 of 21 patients) in those with or without teratoma in the primary tumor, respectively $(\mathrm{P}=0.017){ }^{25}$.In the PC RPLA group in the present series, fibrosis was present in the RP in $21.4 \%$, teratoma in $64.4 \%$, teratoma with malignant transformation/ vital carcinoma in $14.2 \%$. These incidences are similar to those reported by Steyerberg et al. ${ }^{26}$ for PC RPLA in patients with teratoma present in the primary testis tumor in a pooled analysis of six studies. In that report, the investigators found a $32 \%, 54 \%$ and $14 \%$ incidence of necrosis, teratoma and viable carcinoma in patients with teratoma in the primary specimen versus $50 \%$, $30 \%$ and $11 \%$ in patients without teratoma in the primary specimen ${ }^{26}$. On multivariate analysis, patients with no teratoma in the primary specimen had a 2.46-fold increased incidence of necrosis in the RP versus other

MATERIA MEDICA • Vol. 27 • No. 1 • Februar 2011. 
histologic findings compared with those with teratoma in the primary specimen ${ }^{25}$. Leibovitch et al. ${ }^{11}$ reported higher incidence of teratoma in the RP after induction chemotherapy; in their series, 14 of 16 patients with CS IIC-III PTT undergoing PC RPLA had teratomatous elements in the RP, 2 had vital carcinoma, in combination with teratoma or necrosis, and 1 had fibrosis alone. In the series of Heidenreich et al. ${ }^{13}$, of the 6 patients with CS IIC-III PTT undergoing PC RPLA for a residual RP mass, 1 patient had choriocarcinoma in the RP, 1 had MT with neuroectodermal tissue, 3 had MT, and 1 had fibrosis.

In our series, $1(6.6 \%)$ of 15 patient undergoing PC RPLA had a relapse, including 1 with vital carcinoma in the resected RP specimen. Rabbani et al. ${ }^{12}$ reported relapse in $2(11 \%)$ of 18 patients submitted to PC RPLA. Heidenreich et al. ${ }^{13}$ reported death from disease in $5(11 \%)$ of 44 patients; these patients had presented with advanced disease. Leibovitch et al. ${ }^{11}$ reported relapse in $2(13 \%)$ of 16 patients with advanced disease. Together, these data highlight the malignant potential of PTT and support an aggressive approach with PC RPLA.

Our finding of relapses in 3 of 20 patients with PTT submitted to surveillance versus no relapse in 4 patients undergoing primary RPLA supports a recommendation for primary RPLA over surveillance in this setting, given the unpredictable nature of unresected teratoma and its potential for relapse, as well malignant transformation. However, surveillance and RPLA group in CS I with normal values of STMs postorchiectomy had excellent outcome. All patients achieved finally NED status. For patients with PTT with residual mass after chemotherapy for CS IIB-III, our finding of RP disease necessitating PC RPLA in 13 (61.9\%) of 21 patients, support our approach with PC RPLA and resection of PC masses at metastatic site.

\section{Conclusions}

The strengths of our study include large number of consecutive patients, the long duration of follow-up and application of contemporary therapeutic approach. This data underscore the metastatic potential of PTT. The finding of $15 \%$ relapse rate in CS I patients submitted to surveillance, leads to recommendation of primary RPLA over surveillance, Furthermore, a high proportion (51\%) had initially or developed later as relapse metastatic disease and favors an aggressive approach in these patients.

\section{Literature}

1. Sesterhenn IA, Weiss RB, Mostofi FK, et al Prognosis and other clinical correlates of pathologic review in stage I and II testicular carcinoma. J Clin Oncol 1992; 10: 69-78.

2. Fung CY, Kalish LA, Brodsky GI, et al Stage I nonseminomatous germ cell testicular tumor: prediction of metastatic potential by primary histopathology. J Clin Oncol 1998; 6: 1467-1473.

3. Sturgeon JFG, Jewett MAS, Alison RE, et al Surveillance after orchiectomy for patients with stage I nonseminomatous testis tumors. J Clin Oncol 1992; 10: 564-568.

4. Freedman LS, Parkinson MC, Jones WG, et al Histopathology in the prediction of relapse of patients with stage I testicular teratoma treated by orchidectomy alone. Lancet 1987; 2:294-298.

5. Klepp O, Olsson AM, Henrikson $\mathrm{H}$, et al Prognostic factors in clinical stage I nonseminomatous germ cell tumors of the testis: multivariate analysis of a prospective multicenter study. J Clin Oncol 1990; 8: 509-518.

6. Krag Jacobsen G, Barlebo H, Olsen J, et al Testicular germ cell tumours in Denmark 1976-1980: pathology of 1058 consecutive cases. Acta Radiol Oncol 1984; 23: 239-247.

7. Stevens MJ, Norman AR, Fisher C, et al Prognosis of testicular teratoma differentiated. Br J Urol 1994; 73:701-706.

8. Simmonds PD, Lee AHS, Theaker JM, et al Primary pure teratoma of the testis. J Urol 11996; 155: 939-942.

9. Read G, Stenning SP, Cullen MH, et al Medical Research Council prospective study of surveillance for stage I testicular teratoma. J Clin Oncol 1992; 10; 1762-1768. 
10. Abell MR, Holz F Testicular neoplasms in infant and children: I. Tumors of germ cell origin. Cancer 1963; 16: 965-971.

11. Leibovitch I, Foster RS, Ulbright TM, et al Adult primary teratoma of the testis: the Indiana experience. Cancer 1995; 75: 2244-2250.

12. Rabbani F, Farivar-Mohseni H, Leon A, et al Clinical outcome after retroperitoneal lymphadenectomy of patients with pure testicular teratoma. Urology 2003; 62 (6): 1092-1096.

13. Heidenreich A, Moul JW, McLeod DG, et al The role of retroperitoneal lymphadenectomy in mature teratoma of the testis. J Urol 1997; 157: 160-163.

14. Herr HW, La Quaglia MP: Management of teratoma. Urol Clin North Am 1993; 20: 145-152.

15. Foster RS, Baniel J, Leibovitch I, et al Teratoma in the orchiectomy specimen and volume of metastasis are predictors of retroperitoneal teratoma in low stage nonseminomatous testis cancer. J Urol 1996; 155: 1943-1945.

16. Sheinfeld J, Motzer RJ, Rabbani F, et al Incidence and clinical outcome of patients with teratoma in the retroperitoneum following primary RPLND for clinical stage I and IIA NSGCT. J Urol 2001; 165: 153.

17. Argirovic D, Argirovic A, Stanic V Long term outcome after postchemotherapy retroperitoneal lymphadenectomy in patients with pure teratoma. Eur Urol Suppl 2010; 9(2): 236.

18. Argirovic D, Argirovic A Predicting teratoma in the retroperitoneum in men undergoing post-chemotherapy retroperitoneal lymphadenectomy. Eur Urol Suppl 2010; 9(6): 573.

19. Baniel J, Foster RS, Gonin R, et al Late relapse of testicular cancer. J Clin Oncol 1995; 13: 1170-1176.

20. Argirovic D Late relapses following treatment for nonseminomatous testicular tumors according to single centerbased experience. Eur Urol Suppl 2007; 6(2): 157.

21. Argirovic D Late relapses of germ cell testicular tumors following cisplatin-based chemotherapy. Eur Urol Meet 2007; 2(7); 138.

22. Motzer RJ, Amsterdam A, Pieto V, et al Teratoma with malignant transformation: diverse malignant histologies arising in men with germ cell tumors. J Urol 1998; 159: 133-138.

23. Logothetis CJ, Samuels ML, Trinidade A, et al The growing teratoma syndrome. Cancer 1982; 50: 1629-1635.

24. Argirovic D Retroperitoneal lymphadenectomy or primary cisplatin-based chemotherapy in clinical stage B1/B2 nonseminomatous testicular tumors: Long term results of the prospective non-randomized study. Eur Urol Meet 2007; 2(7): 137.

25. Rabbani F, Gleave ME, Copin CM, et al Teratoma in primary testis tumor reduces complete response rate in the retroperitoneum after primary chemotherapy: case for primary retroperitoneal node dissection in stage IIB germ cell tumors with teratomatous elements. Cancer 1996; 78: 480-486.

26. Steyerberg EW, Keizer HJ, Fossa SD, et al Prediction of residual retroperitoneal mass histology after chemotherapy for metastatic nonseminomatous germ cell tumor: multivariate analysis of individual patient data from six study group. J Clin Oncol 1995; 13: 1177-1187.

Address for correspondence:

Djordje Argirovic

Outpatient Clinic “Argirovic", Urology

11.120 Belgrade

Serbia

Tel.: + 381112788498

Fax: +381113290324

E-mail: cvijiceva@yubc.net 